\title{
COSMOPOLITAN Justice AND CRIMinal States
}

\author{
Avia Pasternak \\ The School of Public Policy, University College London
}

\begin{abstract}
:
Cecile Fabre's monumental work Cosmopolitan Peace offers a thorough investigation of the responsibilities that agents incur through their involvement in armed conflict.

However, her analysis fails to acknowledge the central role that states play in initiating and orchestrating acts of war. I argue that states are corporate moral agents, who are morally responsible for their own wrongdoings during an unjust war, and that this argument is compatible with Fabre's cosmopolitan premises. I then suggest that a systematic account of criminal liability in the aftermath of a war should acknowledge the role that states play in orchestrating wars and committing war crimes.
\end{abstract}

A core theme in Cosmopolitan Peace is the distribution of moral, reparative and criminal responsibilities in the aftermath of an unjust war. Cecile Fabre's treatment of this problem is firmly grounded in her cosmopolitan, and fundamentally individualist, outlook. ${ }^{1}$ She argues that the acts of each agent who had a role to play in the war whether as a combatant, a policy maker or a civilian - should be individually assessed in accordance with jus ad bellum and jus in bello criteria. This assessment then serves to determine the scope of each individual player's rights and liabilities in the aftermath of the war - from their right to take part in peace negotiations, to their duty of reparations and their criminal liability.

Taking Fabre's cosmopolitan and individualist foundations as my starting point, In this paper I challenge her treatment (or, rather, lack there of) of corporate moral 
agents. In section $1 \mathrm{I}$ argue that states too are moral agents, who are morally responsible for their wrongdoings during an unjust war, and I show that this idea is not incompatible with Fabre's cosmopolitan premises. In section 2 I proceed to demonstrate that a systematic account of criminal liability in the aftermath of a war should acknowledge the role that states play in orchestrating wars and committing war crimes. ${ }^{2}$

\section{The State as a Corporate Wrongdoer}

Corporate agents in general, and states in particular, are hardly present in Cosmopolitan Peace (PC). The rationale for this omission is found in the following statement: 'at the bar of cosmopolitan justice [...] states are not corporate entities: the rights [and, one may presume, the duties] that they have are in fact rights held by their individual members qua such members. ${ }^{3}$ But should cosmopolitan justice exclude the idea of the state as a corporate entity?

To answer this question we need to separate two possible objections to the idea of corporate moral agency. The first objection is ontological. It suggests that groups cannot acquire an agency that is separate from their members', e.g. because they do not have actual minds and bodies. It will be beyond the scope of this paper to answer this objection in much depth (and, I should add, there is nothing particularly 'cosmopolitan' about it). Instead, I will merely point out that the idea of corporate legal personality is prevalent in most contemporary domestic legal practices. Furthermore, there is a rich body of recent philosophical literature that asserts the corporate moral agency of structured groups. One highly influential account is offered 
by Christian List and Phillip Pettit. This account is entirely compatible with methodological and normative individualism, as it takes groups' desires and beliefs to be constituted by those of their members, and accepts that groups can only act through their members. ${ }^{4}$ Nevertheless, it argues that a group's beliefs and desires can become 'functionally independent' from those of their members, through a decision-making procedure that 'collectivises reason': i.e. it collects members' attitudes on separate premises, and deduces a decision on the basis of the logical combination of members' aggregated attitudes for each premise. ${ }^{5}$ The result is that what the group ends up 'believing' or 'desiring' can be different from what some or even all group members desire and believe. The group then has a 'mind of its own', which supervenes upon, but is functionally independent of, the minds of its individual members. ${ }^{6}$ Such group agents would qualify as moral agents, if they are able to bring into their decisionmaking process considerations about right and wrong. ${ }^{7}$ As moral agents, they can have various mens rea (intention to harm, negligence) and they can also act on these states of mind. To be sure, their actions would be physically carried out by their members, but if they originate from the group's own plans and directives, they are attributable to the group. As List and Pettit conclude, the corporate entity 'has to answer as a whole for what it does at the corporate level, drawing on the resources provided by its members' ${ }^{8}$

List and Pettit's framework can be used to show that the state, at least on the standard Weberian understanding, is a corporate moral agent. States are unified organizational actors, which set and follow laws and principles, and which have stable decision making processes and binding authority structures that ensure organizational autonomy and rational consistency over time (e.g. constitutions, defined role 
responsibilities and internal accountability mechanisms). ${ }^{9}$ As such they meet List and Pettit's requirements for moral agency. States can certainly incorporate moral reasoning into their decision making process, and therefore qualify as moral agents, who can make wrongful decisions - e.g. embark on an unjust war. Indeed, if we accept List and Pettit's ontological premises, we will be led to the conclusion that it could be case that a state endorsees a decision to embark on an unjust war even though few (perhaps even none) of its individual decision makers personally support this final decision. ${ }^{10}$ States can also be corporately negligent. For example, their institutional arrangements or 'corporate culture' can lead to wrongful harms, and when that happens, the state itself is would be at fault for mal practice. Whether or not individual members are also responsible for their participation in, and contribution to, the harmful corporate culture is a separate question. Quite possible many, perhaps even all, individual members would have excuses that would exonerate them from personal blame (e.g. reasonable lack of knowledge at the individual level, or genuine inability to bring about a change of policy). But even if no individual is personally to blame, the state itself could be at fault as the agent that orchestrates the operation of its individual members.

But a second set of worries a cosmopolitan might harbour, and which is nascent in the earlier citation from $C P$, concerns the normative implications of the corporate moral agency thesis. Here two concerns might arise. The first is that if we accept the moral agency of states, we would be acknowledging their moral personality, including their entitlement to moral rights that would compete, and might even take priority over, the moral rights of their individual members. This conclusion would indeed be in direct tension with Fabre's cosmopolitan premises. However, in response I would argue that 
the view of the state as a morally responsible agent does not translate into the claim that the state has the type of moral personhood that grounds primary moral rights protections. Moral personhood may well require additional attributes that states, or corporate moral agents more generally, do not have. For example, some argue that in order to be the locus of primary moral concern an agent must be vulnerable to experiential harm. ${ }^{11}$ Accordingly, whatever rights states might have (e.g. the right to territorial integrity) would be derived from the interests of some moral persons who have the relevant attributes, such as the state's members and other individuals in the world. ${ }^{12}$ This conclusion is compatible with Fabre's cosmopolitan premises.

A different normative concern a cosmopolitan might harbour is that the idea of state moral responsibility would exonerate individual actors from their own responsibility for the wrongdoings they had committed under the orders of, and on behalf of, their state. A soldier who committed a war crime might argue 'the state made me do it', thus denying his own moral liability. But, this defence is not deducible from the corporate moral agency view. Moral responsibility is not zero-sum, and more than one agent can be morally liable for the same wrongdoing. If you cajole me, or order me, to commit a wrong and I submit to your will, it can still be the case that both of us are culpable for our respective contributions to the wrong. So the fact that the state is also liable for wrongdoing does not in itself diminish the liability of those who (wrongfully) execute its desires. ${ }^{13}$

\section{Holding states criminally accountable}


I have argued so far that the idea of the state as a corporate moral agent is compatible with Fabre's cosmopolitanism. I now turn to examine some implications for her account of the criminal liability of agents who committed war-related crimes. As I already noted, Fabre pays exclusive attention to the criminal liability of citizens, policy makers and combatants for their wrongful violations of jus ad bellum and jus in bello. However, if states are corporate moral agents, they too could be subjected to a process of criminal accountability, where they are put to trial, publicly condemned for their crimes, and (where appropriate) punished.

Indeed, subjecting states to criminal prosecution might make particular sense with regard to a specific category of war-related crimes - 'crimes against humanity'. As Fabre notes, a common view suggests that a definitional feature of such crimes is that they are committed by states or state-like institutions. ${ }^{14}$ Richard Vernon, for example, defines crimes against humanity as crimes that involve 'the abuse of state power' and which are carried out through the large-scale administrative capacity and local authority of the state. ${ }^{15}$ Fabre resists the categorization of crimes against humanity solely in light of the identity of their perpetrator, rather than the type of harm the perpetrator inflicts on their victim. ${ }^{16}$ But while her argument is sound, it does not undermine the claim that states are all too often complicit in crimes against humanity as the 'source of the deed', or the 'planner at its origin'. ${ }^{17}$ When that is the case (and, as Vernon suggests, it usually is the case), it is fitting that - if we hold individual actors to account for crimes against humanity - we should also hold states to account as the institutional entities orchestrating the war. Given that states are moral agents, they should be able to respond to the moral reasoning entailed in the process. 
One might argue against this proposal that it requires a too radical revision of international criminal law, which so far resisted attempts to hold states criminally liable for international crimes. But in response, I would note that all modern domestic jurisdictions hold corporate entities criminally liable for serious wrongdoings. In the UK, for example, a corporation can be held liable for manslaughter. ${ }^{18}$ There is nothing conceptually different about the state that prohibits the extension of this practice. Indeed, the idea of state crime is not entirely alien to international law and has been given serious consideration by international lawyers. For example, late drafts of Article 19 of the International Law Commission's Articles on State Responsibility stated that international crimes include 'an act of State which constitutes a breach of an international obligation', and listed crimes such as 'colonial domination' 'slavery, genocide and apartheid'. ${ }^{19}$ This provision was removed from the final version of the Article, due to political pressures (including from the UK). However, the International Court of Justice's ruling on charges against Serbia for genocide concluded that states could in principle be held criminally responsible. ${ }^{20}$ These examples demonstrate that international criminal law is at least conceptually open the idea of state criminality.

However, even if international law could be revised, there are remaining normative difficulties surrounding the idea of holding states criminally liable, and in particular punishing them. ${ }^{21}$ Fabre defines punishment as the imposition by some party $(\mathrm{P})$ on another party (W) of a burden, harm of cost, which $\mathrm{W}$ has a prime facie right not to incur, in response to a wrongdoing committed by W. ${ }^{22}$ When considering the punishment of states, we need to answer two questions: first, can states be punished? Second, may states be punished? 
Let's look at the capacity issue first: once we accept that a state is a corporate entity that is separate from its members, we can accept that it can have its own separate interests. If it has its own interests, it is possible, at least conceptually, to frustrate those interests, as a mean of punishment. The punishment would entail imposing some harm or burden, which in principle the state has a right not to incur, in response to its wrongdoing. Suppose for example we agree that states have a right to territorial sovereignty. As we saw, the deep normative justification for such right is the interests of individuals (e.g. the state's members) in leading a flourishing life. ${ }^{23}$ But conceptually the right attaches to the state, inter alia given that the state - as opposed to the aggregate collection of individual citizens - is the rational and moral agent with the organizational capacity that enables it to exercise this type of right. ${ }^{24}$ Indeed, it is clear that states take their territorial sovereignty to be fundamental interest, and much of what they do in the international arena is aimed at protecting it. It follows that limiting a state's territorial sovereignty in response to its wrongdoing could count as state punishment. $^{25}$

The more difficult question is whether we may punish states. Here too there are two separate considerations. The first is whether the punishment of states fits Fabre's justification of punishment. The second is whether the punishment of states violates considerations of narrow or wide proportionality. I shall take these two issues in turn.

Let's first examine the justification of punishment. In $C P$ Fabre adopts an expressivist and hybrid justification of punishment, according to which the purpose of punishment is to re-establish moral equality between victims and perpetrators. On this view, by violating a victim's right, the perpetrator treats her as less than morally equal. 
Punishing the perpetrator (i.e. imposing a burden, harm or cost) sends a message about their moral parity with the victim, a message that would not be communicated by mere verbal disapproval of the perpetrator's actions. ${ }^{26}$

As we saw, states' moral status is different from that of individuals. So clearly punishing them would not send that message. But we can preserve Fabre's general argument for punishment and revise it to fit the case of corporate wrongdoers: rather than sending a message of moral equality between perpetrators and victims, punishing states would serve to emphasize state's secondary position in our moral universe. After all, states (as well as other corporate agents, like business conglomerates) are powerful entities. They have vast resources and efficient propaganda machines, which often help to obscure the fact that they are merely artificial creations, designed and maintained by individuals, and whose sole purpose is that of serving individuals. The practice of corporate punishment in general, and of punishing states in particular, can send the powerful message that despite their enormous resources, their ability to mobilise populations and to generate feelings of attachment and loyalty, states are not above individuals, morally speaking. Their rights are given to them for a certain purpose, and when they violate that purpose, these rights will be taken away. Indeed, failing to punish states might send the opposite message, that states do deserve some kind of moral immunity. ${ }^{27}$

Punishing states for war crimes can therefore be accommodated within $C P$ 's general justification of punishment. A remaining question is whether such punishment can comply with the standards of narrow and wide proportionality, which Fabre sets as limits to justified punishment. Narrow proportionality refers to the proportionality of 
harm inflicted on the perpetrator. So, for example, Fabre argues that the punishment 'must not degrade the wrongdoer to such an extent to impair his dignity'. ${ }^{28}$ Whether it makes sense to speak of states' dignity in light of their moral capacities is a question that requires further exploration. Answers to that question can inform us on the level of state punishment that is appropriate in specific cases. Clearly some of the punishments I mention below can serve an expressive function without being degrading.

The more difficult issue is that of wide proportionality, which refers to the harm inflicted on agents other than the perpetrator (i.e. third parties). This is a pertinent problem, given the 'distributive effect' of corporate punishment. Suppose for example we impose punitive damages on a criminal state. Inevitably, its citizens will experience losses as result from its reduced capacity to provide them with goods and services (or from increased taxes). Some advocates of corporate punishment dismiss this as a mere side effect, no different to the standard side effects that the punishment of individual criminals often has on their dependents. Such side effects are perhaps a form of 'regrettable injustice', but - so the argument goes - they are not sufficiently severe to undermine the practice of punishing individuals. ${ }^{29}$ However, this reasoning will surely be rejected by Fabre, who forcefully argues that wide proportionality considerations should constrain the punishment of individual criminals, and laments the lack of attention to this issue in current domestic jurisdictions. ${ }^{30}$

What conclusions then, should we draw from the 'distributive effect' of state corporate punishment? Here, I would argue there are three possible strategies that retain the idea of holding states to account and remain compatible with $C P$ 's 
normative framework. The first is simply not to punish states. This strategy has been suggested, for example, by David Luban. On his view, while in domestic criminal law proceedings the trial is the means to the end of punishing those who should be punished, in international prosecutions of criminal atrocities 'the center of gravity lies in the trial, far more than the punishment'. ${ }^{31}$ The trial becomes the public stage where the 'human catastrophe is displayed to the world' and where 'political violence gets relabeled as crime'.32

Clearly, if we accept Luban's solution and merely hold states criminally liable through the trial, we will be going a considerable way, certainly in comparison with the status $q u o$, in sending a message of condemnation for state's criminal behaviour. However, the problem with this solution is that (as Fabre herself notes) mere verbal condemnation might not be strong enough to communicate the seriousness of the crime, or the secondary moral status of states, especially in a world where individual agents do get punished for their war crimes.

A second strategy is to try to punish states in ways that spare their members from incurring the attendant costs. Bill Wringe, for example, argues against the imposition of punitive damages on states, precisely because they have 'spill-over effects' on citizens. Instead, he advocates 'status measures', such as limits on rights of membership in international organizations or rights of diplomatic representation, which have lower direct impact on citizens. ${ }^{33}$ One could add to this list measures that could in fact benefit the citizens of a criminal state. In the domestic setting, one approach to corporate punishment involves placing convicted corporations on probation, which requires the implementation of internal compliance plans, or 
compliance with external monitoring systems and even replacement of leadership. ${ }^{34}$ If parallel measures were imposed on delinquent states, that may well end up benefitting their populations, especially if the state already has a poor record of respect for the human rights of its own citizens.

Whether or not such measures can serve the goals of punishment, including that of deterrence, requires further research. ${ }^{35}$ The final strategy I shall mention does not seek to avoid the distributive effect per se. Instead, it suggests that citizens can be expected to bear at least some of the trickle-down costs of corporate punishment. To clarify, the idea here is not that citizens are also to blame for the relevant wrongs and for that reason should be punished (as a means to condemn their wrongdoing). Rather, the idea is that as a wrongdoer the state has a duty to accept the burdens of punishment, and that its citizens have membership-base obligations to assist their state in discharging this duty. ${ }^{36}$ Conceptually then, these burdens are not different from the burdens that fall on citizens when, for example, their state is charged with compensatory duties to those it wronged in an unjust war. Recent literature has offered various arguments for why citizens incur such liabilities, as well as on the appropriate distribution of this burden between them. ${ }^{37}$ Some focus on the way in which the state (and especially democratic states) act in the name of, or on behalf of their citizens. ${ }^{38}$ Others focus on the way in which citizens participate - even in a nonblameworthy manner- in their state's actions, and as result bear (some) liability for what it does. ${ }^{39}$ Such arguments are compatible with Fabre's own analysis of the reparative duties citizens on the unjust side may bear in the aftermath of a war. ${ }^{40}$

\section{Conclusions}


Cosmopolitan Peace is an ambitious book, offering action-guiding recommendations, backed by rigorous philosophical argumentation, to citizens and policy makers in the world as we know it, who seek to restore justice and peace in the aftermath of a war. I have argued that, in the world as we know it, states play a central role in peoples' minds and imaginations, as motivational sources for action. It would be misguided to ignore the presence of these group agents - not just because they are already embedded in our legal and cultural frameworks - but also because the idea of the state as a corporate agent does not stand in tension with the cosmopolitan principles Fabre wishes to promote. After all, it is a fairly undisputed observation that the state - as an effective rational and moral agent - is necessary for the execution of fundamental cosmopolitan goals, including securing flourishing lives for all individuals. However, if history teaches us anything, it is that if left unchecked, states can all too easily turn into Golems that bring havoc and destruction on their populations. Holding states criminally to account is one important way of acknowledging, but also demystifying and limiting their moral status in our moral universe. As such it fortifies Fabre's cosmopolitan project.

\section{NOTES}

Acknowledgements: I am grateful for very helpful comments on earlier versions from Cecile Fabre, Jonathan Parry, Jeremy Williams and two anonymous referees. I am also grateful for comments made by participants in the workshop on Cosmopolitan Peace at the University of Birmingham, 2017.

${ }^{1}$ Cecile Fabre, Cosmopolitan Peace (Oxford: Oxford University Press, 2016) p. 3.

${ }^{2}$ For lack of space I set aside the case of liability to reparations, though much of what I will say about criminal liability applies there too.

${ }^{3}$ Fabre op. cit.123. Emphasis added. Cf. Ibid, 7.

${ }^{4}$ Christian List and Philip Pettit, Group Agency (Oxford: Oxford University Press, 2011), p. 10.

${ }^{5}$ Ibid. 45-6

${ }^{6}$ Ibid. $65-72$. 
7 Ibid. 158.

${ }^{8}$ Ibid. 76-77.

${ }^{9}$ For elaborations see Toni Erskine, 'Assigning Responsibilities to Institutional Moral Agents: The Case of States and Quasi States', Ethics and International Affairs 15, 1 (2001): 67-86. Francois Tanguay-Renaud, 'Criminlizing the State', Criminal Law and Philosophy 7, 2 (2013): 255-284. Alexander Wendt, 'The State as Person in International Theory', Review of International Studies 30, 2 (2004): 289-316.

${ }^{10}$ As I noted before, List and Pettit show that if a group uses a premise-based decision making procedure, which is essential for the maintenance of rational corporate agency over time, it can reach decisions which none of the members personally supports. List and Pettit op. cit. 56-57.

${ }^{11}$ For elaboration see Kendy M Hess, “"If You Tickle Us....": How Corporations Can Be Moral Agents without Being Persons', Journal of Value Inquiry 47, 3 (2013): 319335.

${ }^{12}$ For one account of the relation between corporate and individual agents' moral rights see Avia Pasternak 'From Corporate Moral Agency to Corporate Moral Rights', The Law \& Ethics of Human Rights 11, 1 (2017): 135-159.

${ }^{13} \mathrm{Cf}$. List and Pettit, op. cit. pp.163-167. An important related question is whether the fact that a reasonably just state orders one to fight a war might serve as a moral defence. Fabre is sceptical (op. cit. 191), but for a contrary view see David Luban, 'Knowing When Not to Fight'. In S. Lazar and H. Frowe (eds.) The Oxford Handbook of Ethics of (Oxford: Oxford University Press), pp. 185-203.

${ }^{14}$ Fabre op. cit. 180 fn. 12.

${ }^{15}$ Richard Vernon 'What Is Crime against Humanity?' Journal of Political Philosophy 10, 3 (2002) p. 243.

${ }^{16}$ Fabre op. cit. 181-182.

${ }^{17}$ Tanguay-Renaud, op. cit. 12.

${ }^{18}$ Celia Wells, Corporations and Criminal Responsibility (Oxford: Oxford University Press, 2001), chapter 6.

19 James Crawford, The International Law Commissions' Article on State Responsibility: Introduction, Text and Commentaries (Cambridge: Cambridge University Press, 2002), pp. 352-353.

${ }^{20}$ Although it ruled that Serbia was not responsible for genocide in this particular case. For disucssion see Anthony F. Jr. Lang, 'Punishing Genocide: A Critical Reading of the International Court of Justice', in T. Issacs and R. (eds.) Accountability for Collective Wrongdoing, (New York: Cambridge Univeristy Press, 2011), pp. 92118.

${ }^{21}$ Another important issue that I cannot comment on in detail is the question of which entity would have the authority to hold states to account. One option would be to apply Fabre's 'universal jurisdiction' approach, according to which an international institution (such as the International Court of Justice) should have the primary jurisdiction, but when international institutions fail to comply, domestic jurisdictions should take the lead (Fabre op. cit. 204-205). This proposal might face the at least one serious challenge that it would threaten the geo-political stability of international relations.

${ }^{22}$ Ibid. 174.

${ }^{23}$ I assume that the right to territorial sovereignty is necessary to secure individual citizens' flourishing lives. 
${ }^{24}$ Dwight G Newman, 'Collective Interests and Collective Rights', American Journal of Jurisprudence 49, 1 (2004): 127-149.

25 cf. William Wringe, An Expressive Theory Of Punishment (London Palgrave, MacMillan 2016), chapter 8.

${ }^{26}$ Fabre op. cit. 175

${ }^{27}$ I focus here on Fabre's specific justification of punishment, which sees it as restoring the moral equality of victims and perpetrators. Other justifications of punishment highlight additional expressive functions, such as communicating the validity of the moral requirements that the perpetrator violated. Punishing states could deliver such a message as well (and a failure to punish them would undermine it). I thank an anonymous referee pressing me to clarify this point.

${ }^{28}$ Ibid. 177.

${ }^{29}$ Nigel Walker, Why Punish? (Oxford: Oxford University Press, 1991), p. 106. Peter French, Collective and Corporate Responsibility (New York: Columbia University Press, 1984), p. 189. Tanguay-Renaud op. cit. pp. 32-33.

${ }^{30}$ Fabre op. cit. 192-193.

${ }^{31}$ David Luban, 'State Criminality and the Ambition of International Criminal Law', in R. Vernon and T. Issacs op. cit. 73.

${ }^{32}$ Ibid. 74-75.

${ }^{33}$ Wringe, op. cit. Chapter 8.

${ }^{34}$ Pamela H. Bucy, 'Corporate Criminal Liability: When Does It Make Sense', American Criminal Law Review 46 (2009): 1437-1457. Cf. Wells, op. cit. pp. 37-38.

35 The effectiveness of corporate punishment on business corporations is disputed. For one influential and somewhat sceptic account see John C. Coffee, Jr., 'No Soul to Damn: No Body to Kick: An Unscandalized Inquiry into the Problem of Corporate Punishment', Michigan Law Review 79 (1981): 389-460.

36 This point is sometimes lost in discussions on corporate sanctions. Martha Nussbaum, for example, denunciates boycotts against academic institutions because they signal that 'all members of the institution deserve condemnation' (Martha Nussbaum, 'Against Academic Boycotts,' Dissent 54, 3 (2007), p. 33. Conceptually, that is not correct (and those who impose such sanctions should take measures to communicate their message in a way that does not implicate the members).

${ }^{37}$ On the question of the distribution of liability between citizens see for example Stephanie Collins 'Distributing State Duties', The Journal of Political Philosophy 24, 3 (2016):344-366. Avia Pasternak, 'Sharing the Costs of Political Injustice' Politics, Philosophy, Economics 10, 2, (2011): 188-210.

${ }^{38}$ E.g. Anna Stilz, 'Collective Responsibility and the State', The Journal of Political Philosophy 19, 2 (2011): 190-208.

${ }^{39}$ E.g. Avia Pasternak 'Limiting States' Corporate Responsibility' The Journal of Political Philosophy 21(4) (2013): 361-381.

${ }^{40}$ Fabre accepts that the participatory framework could serve to explain why ordinary citizens and soldiers are personally liable to contribute to reparations for war crimes. However, she remains sceptical that, in practice, this basis would have a sufficiently wide application, as on her account many citizens would not be participating in the war in the morally relevant sense (Fabre op. cit. 158). In contrast, Pasternak (Ibid.) argues that most citizens would be supporting the institutions of their state in a way that grounds the duty to accept a share of their state's liabilities for wrongdoing. 